\title{
Cortical Bone
}

National Cancer Institute

\section{Source}

National Cancer Institute. Cortical Bone. NCI Thesaurus. Code C52714.

The dense or compact outer layer of tissue that covers the bone. 